\title{
FRENCH JUDGMENTS SUBJECT TO IMMEDIATE APPEAL
}

\author{
WALlace R. BAKER*
}

\section{INTRODUCTION}

Rules determining what types of decisions are immediately appealable under French law are found in the new Code de procédure civile. ${ }^{1}$ Articles 543, 544, and 545 of the Code, which are comparable to sections 1291, 1292, and 1651 of the United States Judicial Code, ${ }^{2}$ are the rules of general application in the French appellate scheme. Specific rules relating to immediate appeal from judgments concerning choice of forum and provisional relief, discretionary appeals, and other types of appeals are found elsewhere in the Code.

The purpose of this article is to examine the French system of appeals ${ }^{3}$

Copyright $\odot 1984$ by Law and Contemporary Problems

* Partner, Baker \& McKenzie, Paris, France. This article is drawn from a portion of a treatise on French civil procedure which the author is preparing for publication.

1. Nouveau Code De PROCÉdure CIVILE [C. PR. CIV.], (66e ed. Petits Codes Dalloz 1984). The new Code de procédure civile will hereinafter be referred to as the Code or the new Code. All textual references to articles will be to articles of the new Code unless otherwise indicated.

2. 28 U.S.C. $\S \S 1291,1292,1651$ (1982).

3. The following provides some background on the French legal system and lists and defines the different types of French judgments; under the French system, the type of judgment determines the type of appeal available.

A. The French Court System.

France is not organized into a federal system and therefore has no state courts, since it has no states with separate constitutions, bodies of law, or administrations. All courts are emanations of the central government. Although significant changes have occurred recently in decentralizing the administrative and political bodies, adoption of a federal system of courts is not contemplated.

France does, however, have a system of specialized courts. In the French system, courts are divided into geographic subdivisions, with one group of courts, Tribunaux de Grande Instance, having residual jurisdiction over matters not specifically assigned by law to specialized courts. Courts specialized according to subject matter include the Tribunaux d'Instance for small claims, guardianship, local electoral matters, and other questions; Conseils de Prud'hommes (labor courts) for employee-related disputes; Tribunaux de Commerce (commercial courts) for businessmen's disputes; Tribunaux Administratifs (administrative courts) for disputes with the government public services; and Commissions de Premiëre Instance de la Securité Sociale (Social Security Commissions) for Social Security disputes. Tax questions may be litigated in either the administrative courts or the civil courts, depending upon the type of questions involved. Except for some small cases and administrative appeals, most decisions in these courts are appealable within one month of notification of judgment to one of the thirty appellate courts which have appellate jurisdiction for the above-mentioned courts.

In France, there are no juries to find facts in civil and administrative cases. To a common law lawyer, there seems to be a predilection for written proof (rather than oral testimony) and written court procedures, except in the lower courts, where the parties sometimes appear without lawyers and the court procedures are simpler. The oral examination of witnesses is unusual, and when it occurs the judge does it, not the lawyers. Primary reliance on written proof may evidence skepticism about the truth of oral testimony. Although the French system allows the parties no recourse to a jury in civil cases, the parties can secure a complete review of facts and law in the appellate court.

Laymen, nevertheless, do have a place in French justice. The laymen, however, are specialized, which 


\section{governed by the Code in order to provide the reader with a basic understanding of}

indicates more of a reliance on specialization than on the concept of folk justice. Judges in commercial courts are businessmen who are often without legal training; in labor courts, there are lay representatives of employers and employees; and in social security commissions, a judge is assisted by a representative of the employees and an employer representative who are not required to have legal training. As a result, laymen render judgments which are not always in proper legal form and which have caused difficulties upon appeal.

B. Types of Review.

In the French system, review can be had through reconsideration either by the court rendering the decision or by a different court, depending upon the type of decision being reviewed and the type of review sought. The following list gives a general outline of the types of review available and the courts by which that review is made:

Appel. An appeal (appel) of a lower court decision before the court of appeals is the usual form of review. Such review covers both law and facts. Appeals of lower administrative court decisions lie to the Conseil d'Etal acting in an appellate capacity. It also reconsiders both law and facts.

The general rules relating to civil appeals and general rules relating to other "recours" are found in articles 527-70. In addition, appellate court rules are set forth in articles 899-972; however, articles 78, $79,89,91$, and 95 in the section entitled "Defenses" refer to appeals of jurisdictional, procedural, and other defenses.

Correction or interpretation. Review by the court to correct or interpret a judgment it granted is allowed by articles 561 and 562 in the part of the Code relating to judgments.

Opposition. An opposition is a review of a default judgment, governed by articles $571-78$, by the court which granted the judgment. Since, like an appeal, it is classified as an ordinary review open to all litigants, it is placed in the same subtitle.

Contredit. A contredit is an accelerated review of choice-of-forum questions before the court of appeals. The rules relating to this procedure are found under the fifth title, "Means of Defense," in articles 80-94.

Tierce opposition. Tierce opposition is a remedy for third parties against a judgment, usually brought in the court rendering the judgment unless it is raised in another proceeding. The rules governing this review are found in articles 579-81, and are the first of those dealing with extraordinary reviews.

Recours en revision. Recours en revision, presented in articles 593-603, is the second extraordinary review set forth in the new Code. It is raised in the court in which a judgment is rendered, in cases in which false statements or documents or fraud are discovered after the judgment.

Prise à partie. Prise à partie is an extraordinary review by the court of appeal existing in articles 505-16 of the old Code of Civil Procedure against judges who are not professional judges (i.e., commercial court and labor court judges). It lies against judges who are personally responsible, as a result of a special legal provision, for fraud, willful negligence (faute lourde), accepting bribes, or refusal to render justice (déni de justice). The French National Government is liable for damages but has a right of recovery against the judge.

Pourvoi en cassation. A pourvoi en cassation to the French Supreme Court (Cour de cassation) is the most important extraordinary review. According to article 604, it is available to correct errors of law. Types of legal errors which lead to reversal (cassation) are lack of jurisdiction of the court granting judgment, failure to give good reasons (defaut de motifs), failure to give a legal basis (manque de base légale) for the decision, and action by a court beyond its powers (excés de pouvoir). Reversal is also possible in case of contradictory lower court judgments. General provisions relating to this procedure are found in articles 604-39; special rules relating to the Cour de cassation are set forth in articles 973-1037.

Appeal to the Conseil d'Etat. The Conseil d'Etat also serves as a supreme administrative court, acting somewhat like the Cour de cassation, in reviewing court judgments where no appeal is available.

C. Review in the Appellate Court.

Ordinary Review. Appeal to the appellate court and the Conseil d'Etat (acting as an appellate court for administrative court decisions under the French system unless limited by the parties) provides for a complete reconsideration of facts and law on all matters submitted to the lower court. An opposition is a review that opens up for consideration questions of fact and law.

The right to appeal (or opposition) is considered a fundamental right-a guaranty of securing justice. It is referred to in terms of court structure as the two-tier system (double degré de juridiction). It allows recourse to a higher court provided the case is important enough and there are not special policy reasons (such as an urgent need for certainty) against allowing any appeal.

Both appel and opposition are considered forms ordinary review, meaning that every litigant may take advantage of them. The right to exercise either does not require a party to be in one of the special situations required for extraordinary appeals. In addition, before extraordinary review is granted, a party must 


\section{that system and a point of reference for comparing the French system with those}

first have recourse to an ordinary review. A third distinction between the two types of review is that an ordinary review suspends execution while an extraordinary review, with a few exceptions, does not. $A$. Jauriret, Manuel de Procédure Civile et Voies d'Exécution 158 (1980).

Extraordinary Review. Review by the supreme court and the Conseil d'Etat (when not acting as an appellate court) is limited to errors of law. Review also exists in the supreme court for certain final decisions (en dernier ressort) in the lower courts where no appeal lies to the appellate court because of the small size of the litigation.

The Conseil d'Etat, in accepting a pourvoi from a lower court judgment, reviews "the existence of the facts," unlike the Cour de cassation. Tierce opposition, recours en personne, and prise à partie are also classified as extraordinary procedures of review.

New Maller Considered on Appeal. The general rule of French appellate procedure is that matters not considered in the lower court should not be considered on appeal (l'effet devolutif). However, if the lower court judgment dismissed the case and the appellate court finds the dismissal to be in error, it may enter judgment on the merits and consider matters which were not considered by the lower court. (This is referred to as ivocation.)

Article 564 does not allow consideration in the appellate court of new claims, except that new parties can intervene or be joined at the appellate level, and new matters can be injected where they are needed to deny claims of adversaries or where they complement claims made in the lower court. Counterclaims can also be filed for the first time on appeal. It has been held that a different theory can be alleged for the first time on appeal if the same result is sought, but the supreme court in one case reversed because the cause was considered of a different nature. Judgment of Sept. 22, 1983, Cass. civ. com., Gaz. Pal., Feb. 3, 1984 , No. 2435, at 33 (plaintiff claimed unfair competition in the lower court and infringement of a design on appeal).

D. Classification of Judgments.

French judgments can be grouped into roughly ten classes. The classification of a judgment under the French system is significant because it determines the type of review available from that judgment. The following discussion briefly summarizes and explains the different judgment classifications under French law. See J. Vincent \& S. Guinchard, Procédure Civile, 1 1 $727-743$ (20e ed. 1981).

All judgments are first classified as either contradictory or default judgments. A true contradictory judgment is one handed down in a case where the defendant has been served and both parties appear. Default judgments are, of course, judgments handed down in cases where one party fails to appear. Also, there are judgments which are decmed contradictory (réputé contradictoire)_-judgments that are handed down in cases where either there is personal service on the defendant and a failure to appear on the defendant's part or there is no personal service on the defendant but the judgment is subject to appeal.

Final judgments of the lower courts are also classified into two further categories. In the first of these classes are judgments premier ressort, which are those judgments subject to appeal. The second class consists of judgments demier ressort, which are not subject to normal appeal but are subject to review pourvoi in the supreme court.

The other classes of judgments consist of those judgments which are not (or are not necessarily) final judgments. One such class is the class of definitive judgments. Definitive judgments are those which decide a part of or the whole case and are not open to reconsideration by the judge. Judgments on the substance of the dispute and on questions of competence, along with judgments in cases relating to the nullity or validity of an act of procedure, are considered definitive. The definition of a definitive judgment is broader than that of a judgment on the substance (sur le fond).

Provisional judgments are those over which the judge retains jurisdiction to reexamine his decision and change his mind; they are not res judicata (autorile de la chose jugee) with regard to decisions taken in the litigation on the merits (au principal). This category includes several different types of provisional judgments. For example, there are those rendered by a single judge when both parties appear (ordonnance de réferé), ex parte judgments (ordonnance sur requete), and orders issued by the preparatory judge (juge de la mise en etat) charged with supervising the preparation of the case. During the course of litigation, provisional judgments can be granted to protect a party during the course of the proceeding; others are entered with a final judgment but are by nature subject to revision, such as the granting of custody or the fixing of alimony.

The rules of reviewability relating to provisional judgments differ. For example, while it is true that urgent decisions by single judges are not res judicata as to the substance of the matters in issue, they should not be modified by going back to the same judge unless circumstances have changed. Ex parte decisions, on the other hand, may be retracted or modified by the judge who made the decision even if another judge is presiding over the separate legal proceeding dealing with the substance of the matter.

$\therefore$ 's, $\therefore$

Interlocutory judgments (jugements avant de dire droit) are those that are not res judicata, remain: within , 
used in the United States. The article will review the general rules which existed under the old Code de procédure civile, set forth the new general rules, discuss the application and interpretation of the new rules, review cases in which immediate appeals have been refused, and, finally, summarize briefly some of the problems with the French system and the differences between the French and American rules.

II

\section{The Old Code of Civil Procedure}

\section{A. General Provisions}

Until 1942, article 31 of the old Code of Civil Procedure, which appeared in the first book entitled Tribunal d'Instance (lower court), prohibited appeals from purely "preparatory" as distinguished from "interlocutory" decisions. ${ }^{4}$ The law of May 23, 1942, ${ }^{5}$ however, created a new article 451 in the third book under the title Cours d'Appel (courts of appeal), which authorized appeals from all interlocutory judgments (tous jugements avant de dire droit) on the conditions for accelerated procedure set forth in articles 452 and 453.6 Still later, on December 22, 1958, Décret

the court's jurisdiction to vacate or otherwise modify, and are only exceptionally subject to appeal. They are rendered before the judge reaches a final decision on the substance of the litigation. These judgments generally include those orders requiring investigation of the facts (hearing witnesses, appointing an expert, or requiring testimony of the parties) and are procedural in nature. A second category of interlocutory judgments includes temporary measures to protect one of the parties during the course of the litigation.

Mixed judgments (jugements mixles) are those which decide a matter of substance and order investigation of the facts or provisional relief. They are at the same time definitive and interlocutory judgments. An example is a decision of liability in an autombile accident and a decision to name an expert to determine the amount of the damage; such a decision is definitive with regard to the principle of liability but interlocutory in that it orders an expert to report on the amount of damages.

Finally, judgments rendered or measures taken relating to court administration (mesures d'administration judiciaire) are procedural decisions which are not subject to appeal. C. PR. CIV. art. 537 (66e ed. Petits Codes Dalloz 1984).

4. Article 31 provided:

Preparatory judgments are not subject to appeal until final judgments and jointly with the appeal from such judgments, but the execution of preparatory judgments will not prejudice rights of parties to appeal even if they do not object or reserve their rights.

C. PR. CIV. art. 31 (33d ed. Codes et lois usuels, Code d'audience, Dalloz 1969) (translated by the author).

5. Law No. 556 of May 23, 1942, 1942 Journal Officiel de la République Francaise [J.O.] 2035.

6. Article 451 provided:

In all matters, except for those for which appeals are prohibited by law, all interlocutory judgments (tout jugement avant dire droit) are subject to appeal before final judgment, but only under the conditions indicated in the two articles that follow.

Id. art. 451 .

Article 452 provided that:

The time to appeal will be in this case fifteen days and notice of appeal (acte d'appel) may be served at the agreed address (domicile élu). The appellant must, or be foreclosed, effectively begin his appeal within one month by simple act. Within the same time period, the procedural lawyer (avoué) of the appellant should file the declaration prescribed by Article 457 in the clerk's office.

Id. art. 452 .

Article 453 specified:

In this case the appellate jurisdiciton shall also decide the case at the latest one month from the date it had notice of the appeal.

Id. art. 453. This rule was rarely respected. 
No. 58-12897 introduced the new article 258, which specified that a decision ordering the testimony of witnesses (enquête), or one rejecting it, was not subject to appeal except when combined with a judgment on substantive issues (sur le fond).

Generally, then, if a court order included not only further preparatory or investigative measures (mesures d'instruction), but was combined with a decision which was in part on substantive issues, it became a jugement mixte, in which case the usual rules relating to appeals (e.g., longer notice of appeal period) ${ }^{8}$ applied. This characterization, however, was not applicable in all cases where substantial issues were determined. For example, if the court granted a divorce but also ordered a hearing on the allegations of the opposing party, an appeal limited to the latter decision did not lie, since the decisions were considered to be independent. ${ }^{9}$

The coexistence of articles 31 and 451 produced considerable uncertainty and confusion, and the result was that the parties appealed all orders to avoid being foreclosed. In addition, appeals were used for dilatory purposes, to defer a decision on the merits. ${ }^{10}$ It was under these circumstances that the old Code became ripe for reform.

\section{B. The Ministry of Justice Reforms of the Civil Code in the 1970's}

Despite very considerable modifications from the 1930's through the 1960's, the prior civil code dated to a great extent from the Code of Civil Procedure of 1806 a Napoleonic code which was not admired as much as the civil code. It was drafted by practitioners who were imbued with old formalism dating from the seventeenth century, and, as explained above, was a less than orderly system. The new Code represents a major reform of French appellate procedure resulting from a series of executive orders (Décrets) in the early 1970's. ${ }^{11}$

The reform, which was related to the 1972 reform of the judicial professions, was neither a legislative effort nor a product of rules issued by the courts. Under the 1958 French Constitution, civil procedure became a subject which could be regulated by the executive branch rather than the legislature except for certain fundamental principles, such as the requirement of public trials, rights of defense, and equality of citizens under the law. Criminal procedure, however, along with some areas of substantive law such as status of persons, private property, labor law, and estates, remained within the legislative orbit. The creation of new courts and the rights, duties, and status of judges were delegated by the legislative branch to

7. Décret No. 58-1289 of Dec. 22, 1958, 1958 J.O. 11608.

8. Judgment of Jan. 12, 1962, Cass. civ. 2e, 1962 Dalloz, Jurisprudence [D. Jur.] 237; Judgment of Dec. 21, 1964, Cass. civ. Ire, 1965 Dalloz-Sirey, Jurisprudence [D.S. Jur.] (Sommaires) 60; Judgment of Jan. 7 , 1967, Cass. civ. 2e, 1967 [D.S. Jur.] (Sommaires) 68.

9. Viatte, L'Appel du jugement ordonnant une mesure d'instruction, $1974 \mathrm{Gaz}$. Pal., 2e semestre doctrine 837.

10. N. de Puybusque, De l'appel des jugements avant dire droit, 1976 Gaz. Pal., 2e semestre doctrine 700. This paragraph and portions of part III of this article are drawn in part from de Puybusque and from Viatte, supra note 9.

11. Decret No. 71.740 of Sept. 9, 1971, 1971 J.O. 9072, 1971 Dalloz-Sirey, Ligislation [D.S.L.] 362; Décret No. 72-684 of July 20, 1972, 1972 J.O. 7860, 1972 D.S.L. 438 ; Décret No. $72-788$ of Aug. 28, 1972, 1972 J.O. 9300, 1971 D.S.L. 475; Décret No. 73-1122 of Dec. 17, 1973, 1973 J.O. 13660, 1974 D.S.L. 7; Décret No. 75-1123 of Dec. 5, 1975, 1975 J.O. 12521,1975 D.S.L. 426. 
the executive branch by a grant of special powers to regulate by ordinances. ${ }^{12}$ The reform was accomplished by the Ministry of Justice upon the advice of a commission instituted by an executive order (arrêtê) on April 4, 1969. ${ }^{13}$ This commission was made up of judges, professors, government lawyers, and practitioners; however, neither this commission nor a subcommission set up to do the drafting was as active as the Ministry of Justice. The Council of State (Conseil d'Etat) - the supreme administrative court, acting in its administrative capacity- reviewed the work of the Ministry of Justice. ${ }^{14}$

One major reform was made in 1972, when the abrogation of article 31 of the Code of Civil Procedure attempted to do away with confusion in the case law, which failed to draw a satisfactory distinction between a "preparatory" judgment and an "interlocutory" judgment (a distinction forced upon the courts by the articles of the old Code mentioned above). Under the old rules, an interlocutory judgment was subject to immediate appeal because it was considered to have an effect on the substantive issues and was not entered unless the court had implicitly reached a conclusion on one or more substantive issues. In the new Code of Civil Procedure, the term "preparatory" is not used. "Interlocutory" (avant de dire droit) judgments is the term utilized for both preparatory and interlocutory judgments. Another term, "measures of judicial administration," is also used.

The Code is currently composed of four books, which were codified by Décrets No. 75-1123 of December 5, $1975^{15}$ (Books I and II) and No. 81-500 of May 12, $1981^{16}$ (Books III and IV). The first book sets forth dispositions applicable to all courts; the second contains special rules relating to each jurisdiction; the third book deals with specific subject matter, such as persons, property, matrimonial regimes, divorce, estates, gifts, obligations, and contracts; and the fourth book deals with arbitration. The last book, which is yet to be completed, deals with execution of judgments. The old Code of Civil Procedure still applies to this subject matter.

III

The New Code of Givil Procedure

A. General Provisions-Articles 543, 544, and 545

The articles in the new Code of Civil Procedure describing judgments subject to appeal are articles 543, 544, and 545, which provide as follows:

Article 543-An appeal lies in all types of cases including non-contentious cases (gracieuses)

12. Professor Perrot notes that the distinction between what remains in the legislative "islands" and what may be regulated by the executive is not easy to make. $1 \mathrm{R}$. PERrot, Droit Judicaire Privé, Les Cours De DroIt 13-15 (1980).

13. J. VINCENT \& S. GuinChaRD, supra note 3, at 19. This arrêté was not published in the Journal Officiel.

14. The executive branch makes rules of civil procedure without legislative control. This results in speed and efficiency but also allows a handful of civil servants to impose their personal opinions on the rules of civil procedure and to repeal legislative acts (prior rules of civil procedure). Id. at 15 ; see also J. VINCENT \& S. GUINCHARD, supra note 3.

15. 1975 J.O. 12521,1975 D.S.L. 426.

16. 1981 J.O. 1380 , 1981 D.S.L. 222. 
against judgments in lower courts unless otherwise provided. ${ }^{17}$

Article $544-J u d g m e n t s^{18}$ which decide, in the section of the judgment containing the decision (dispositif or holding), some of the substantive issues (une partie du principal) and order factual investigation or a temporary measure, may be immediately appealed as in the case of judgments which decide all the substantive issues (tout le principal). The same applies when the judgment rules on a procedural defense (exceptions de procédures) ${ }^{19}$ or dismisses the case (fin de non-recevoir) ${ }^{20}$ or any other incident which terminates the case. ${ }^{21}$

Article 545-Other judgments are not subject to appeal independently from judgments on substantive issues (sur le fond) except in cases specified by law. ${ }^{22}$

The substantive issues referred to in article 544 are defined in the second paragraph of article 480. That article deals with this question as follows: "The substance (principal) is the purpose of the litigation as defined by article 4."23

The purpose of the litigation, according to article 4 , is determined by the complaint and answer as modified by other claims (demandes incidentes) if they are reasonably related to the original claim (lien suffisant). ${ }^{24}$

In certain situations a judge retains jurisdiction to modify his judgment. Article 481 provides that once a judgment is rendered, the judge has no further jurisdiction over the questions decided except to retract his decision in case of opposition (to vacate a default judgment), tierce opposition where a third party attacks the judgment, or if the decision is subject to revision for reasons such as fraud, important new evidence, or discovery of false documents. He may also, at the request of one of the parties, intepret this judgment if it has not been appealed, or correct formal errors or omissions. ${ }^{25}$

Other situations where jurisdiction is retained by the judge are found in a section dealing with interlocutory judgments (jugements avant de dire droit). Article 482 defines an interlocutory judgment as a

judgment which, in the section of the judgment containing its decision, only orders fact finding or a provisional measure, and does not have the effect of res judicata relating to the substantive issues (au principal). ${ }^{26}$

Article 483 specifies that interlocutory judgments (jugements avant de dire droit) do

17. C. PR. CrV. art. 543 (66e ed. Petits Codes Dalloz 1984) (translated by the author).

18. Case law has interpreted the word "judgments" to encompass all court orders including "ex parte" and other orders entered by a single judge, such as those authorizing or refusing garnishment of salaries. Judgment of July 13, 1978, Cour d'appel, Paris, 1980 D.S. Jur. 45; Judgment of Mar. 4, 1981, Cass. civ. 2e, 1981 Bulletin des ârrets de la Cour de cassation, Deuxiéme section civile [Bull. Civ.] II No. 50, at 34. Contra Judgment of Dec. 12, 1975, Cour d'appel, Paris, 1976 Gaz. Pal., ler semestre doctrine 332.

19. Under exceptions de procédures are grouped such defenses as lack of jurisdiction where special review to the appellate court lies, called a contredit. Other matters covered under this rubric are litispendence, joinder, deferral to allow more time for action (such as to take any inventory), and procedural nullity.

20. Les fins de non-recevoir, which are dealt with by articles 122 through 126 relate to procedures for dismissal of the case without an examination of the substance. Grounds supporting a fin de non-recevoir include no right to sue, lack of standing, lack of legally protected interest, running of the statute of limitations, a fixed delay required before filing suit, and res judicata. These issues may be raised at any point in the proceedings subject to the judge awarding damages against a party who intentionally defers raising these matters for dilatory reasons.

21. C. PR. CIV. art. 544 (66e ed. Petits Codes Dalloz 1984) (translated by the author).

22. Id. art. 545 .

23. Id. art. 480 .

24. See id. art. 4.

25. Id. art. 481 .

26. Id. art. 482 . 
not result in the judge losing jurisdiction over the dispute (ne déssaisit pas le juge). ${ }^{27}$ However, Professor Perrot notes that even interlocutory orders should not be changed unless circumstances change. ${ }^{28}$

\section{B. General Rules of Review by the Supreme Court}

Limited review by the supreme court is accomplished by a procedure which is not referred to as an appeal but as a pourvoi. Two articles in the new Code set forth the rules as follows:

Article 606-Judgments not subject to appeal (en dernier ressort) which decide, in the section of the judgment containing the decision (dispositif or holding), some of the substantive issues and order factual investigation or a temporary measure are subject to a pourvoi, as in the case of judgments not subject to appeal (en dernier ressort) which decide all of the substantive issues (tout le principal). 29

Article 607-Judgments not subject to appeal which decide upon a procedural defense, dismiss the case, or any other incident which terminates the case are also subject to review by means of a pourvoi to the supreme court. ${ }^{30}$

\section{IV}

\section{The INTER PRETATION OF ARTICLE 544 BY THE COURTS}

A. Mixed Judgments

A preliminary problem, relating to a definition of a mixed judgment (jugement mixte), arises under article 544. An example of a mixed judgment is one where the defendant is held liable in an automobile accident (decision on the substance) and an expert opinion is ordered to determine damages. This is so because ordering of an expert depends upon a finding of liability. If the two matters (substantive and interlocutory) were entirely independent, however, the decision would not be considered a jugement mixte.

B. An Implicit or Explicit Decision on the Substance in the Reasoning Portion of the Judgment

Another problem posed by article 544 is that a lower court judge, particularly if he is a lay judge of the commercial court, labor, or rural lease court, may draft the judgment in an incorrect form, placing decisions on substance in the reasoning part of the judgment and forgetting to reincorporate those decisions at the end of the judgment where the holdings are listed as a matter of form. This problem was referred to as motifs decisoires (decisive reasoning) in a number of judicial decisions under the prior rules, and was characterized as a decision on the substantial issues which could serve as a basis for an appeal. In light of the adoption of article 544, however, most of the chambers of the supreme court have an increasing tendency not to follow prior case law in this regard. The first civil chamber has nevertheless stated in one case that the section of the judgment containing the holdings

27. Id. art. 483 .

28. 2 R. Perrot, supra note 12, at 634-35 (1980).

29. C. PR. GIV. art. 606 (66e ed. Petits Codes Dalloz 1984).

30. Id. art. 607. 
implicitly made a decision on substantive issues as well as on a preparatory or interlocutory issue and therefore it had a mixte character. ${ }^{31}$ The result in this case, reached through somewhat different reasoning, is identical with those in prior decisions which accepted the theory of motif decisoire in allowing an immediate appeal.

The labor law chamber of the supreme court has held a labor court decision subject to appeal because it named an expert to determine damages for an employee having the status V.R.P. (commission salesman with rights to an indemnity for clientele he acquired for his company) even though the statement of his status as V.R.P. was in the reasoning part of the judgment and not in the section of the judgment containing the holdings. The labor law chamber held that there was an implicit decision in the holding, and that the issue thus decided was an essential part of the dispute. ${ }^{32}$ The third chamber of the supreme court has also decided that an immediate appeal was possible in a case of rescission of the sale of real estate on the ground that the price was too low (lésion), where the court was of the opinion that a substantial issue had been decided. The judgment stated that the facts were such as to make it likely that there was lésion and an expert was appointed. ${ }^{33}$

\section{Refusals to Dismiss Based on Important Procedural Matters Which Would Terminate the Litigation}

When the court refuses to dismiss a case is there a question of principal (a substantive issue)? These situations arise when a court refuses to dismiss an action on the ground that the plaintiff has no right to sue, lacks the capacity to sue (capacite de jouissance et d'exercice) or the status to sue (qualité), is not considered to have an interest that is protected by law, or is barred by the statute of limitations. Various chambers of the supreme court have held that a ruling not to dismiss in such cases is not the principal ${ }^{34}$ and the decision is not subject to immediate appeal. Some legal scholars, however, believe that preliminary decisions which can end litigation based on allegations of irrecevabilité or fins de non recevoir should, when coupled with a preparatory or interlocutory order, be considered a part of the principal for the purposes of article 544. ${ }^{35}$ On the other hand, if the lawsuit is dismissed for one of the above reasons, it is subject to appeal under the last sentence of article $544 .^{36}$

\section{Improper Acts of Lower Courts}

Appeals have been authorized for abuse of power (excés de pouvoir) from normally nonappealable decisions of conciliators of the labor court requiring the

31. Judgment of Apr. 26 1977, Cass. civ. 1 re, 1977 Bull. Civ. I No. 145. For a case decided prior to the reform, see Judgment of Apr. 5, 1965, Cass civ. 2e, 1965 Bull. Civ. II No. 363, at 249 (cited in J. VinCENT \& S. GuinchaRD, supra note 3 , at 695 n.1).

32. Judgment of June 10, 1976, Cass. soc., 1976 Bull. Civ. IV No. 356, at 294.

33. Judgment of June 29, 1977, Cass. civ. 3e, 1978 Juris-classeur périodique, la semaine juridique [J.C.P.] II No. 18824.

34. See J. VINCENT \& S. GUinchard, supra note 3, \ 743.

35. Id.

36. See supra text accompanying note 21 . 
rehiring of a terminated employee. ${ }^{37}$

\section{E. Violations of Fundamental Rights}

If a judgment fails to respect the rights to answer and defend oneself against the other party's claims (principe du contradictoire) it is subject to immediate appeal. This was held to be the case when an order was issued to appoint an expert to inform himself of the contents of certain documents when the opposite party was not present. ${ }^{38}$ A violation of a fundamental principle was held to be a matter of substance which went beyond a simple fact-finding measure.

\section{$\mathrm{V}$ \\ Review of ChOICE OF Forum JudGMEnTs, CONTREDITS, AND APPEALS}

Procedural rules for reviewing judgments relating to the choice of forum (exceptions d'incompétence) are set forth in articles 75 through 99 relating to contredits and appeal. Two types of jurisdictional questions may be raised-subject matter jurisdiction and territorial jurisdiction.

\section{A. Contredit ${ }^{39}$}

In 1958 a special immediate and accelerated review of choice of forum judgments by the appellate court, called contredit (to contest jurisdiction), was provided where no decision was made on the merits. In harmony with the need for speed, the question of jurisdiction must be raised with other procedural matters which would result in dismissal or suspension of the litigation before raising defenses on the merits. ${ }^{40}$ In conformity with a judge-directed proceeding, such decisions were sometimes considered more an administrative determination. The resolution of jurisdictional problems, however, often requires resolution of substantive problems of importance to the litigants. Even if important issues on the merits are resolved in order to solve the jurisdictional issue, the accelerated contredit procedure nevertheless applies. ${ }^{41}$

A contredit is available neither for review of a provisional order (ordonnance de réferé) nor for the conciliation judge's orders in separations or divorces. ${ }^{42}$

The contredit procedure must be begun within fifteen days of the lower court judgment (the time period for taking an appeal is normally one month from the date the judgment is issued, except in urgent matters). It is filed with the lower court clerk who notifies the other party and transmits the judgment and the file to the appellate court where the chief justice fixes a date for hearing as soon as possible. Although theoretically the issue is an administrative problem for the courts,

37. Judgment of March 20, 1975, Cour d'appel, Paris, 1975 Gaz. Pal. ler semestre doctrine 376 (cited in J. VINCENT \& S. GUINCHARD supra note 3 , ๆ 936, at 837 n.2).

38. Judgment of Jan. 11, 1978, Cour d'appel, Paris, 1978 Gaz. Pal., ler semestre (Sommaire) 208.

39. Rules relating to coniredits are set forth in C. PR. ClV. arts. 80-91 (66e ed. Petits Codes Dalloz 1984).

40. Id. art. 74 .

41. See 1 R. PERROT supra note 12, at 259

42. C. PR. GIV, art. 98 (66e ed. Petits Codes Dalloz 1984) 
the parties may provide written arguments. ${ }^{43}$ Damages or fines acording to article $88^{44}$ may be assessed against a party utilizing a contredit for dilatory purposes.

\section{B. Appeals}

Not all jurisdictional matters are resolved by the contredit procedure. If jurisdiction of an administrative court is invoked or decided sua sponte, only an appeal is available-unlike the case where a foreign court or arbitral tribunal's jurisdiction is invoked and the appropriate procedure is a contredit. ${ }^{45}$ Appeal is also the only means of review available when a judgment declares the court competent and enters a judgment on the merits. ${ }^{46}$ On appeal, if the appellate court rules that the lower court had no jurisdiction, it may, in some circumstances, nevertheless enter judgment on the merits. This is so if it decides that a different lower court is competent, and the appellate court is the one with jurisdiction over appeals from that lower court. ${ }^{47}$ If a lower court judge sua sponte declares his court is without jurisdiction, a review of his judgment is by way of a contredit. ${ }^{48}$

If upon an exception de procédure raised by a party a judge declares his court competent but decides not to render a judgment on the merits, the case is stayed fifteen days to allow the other party to file a contredit, ${ }^{49}$ which must contain reasons upon which it is based. If a contredit is filed, the proceeding is stayed further until the appellate court renders its decision.

If the judge rules that his court is not competent and the matter should be brought before a criminal, administrative, arbitral, or foreign court, he dismisses the case to allow the parties to begin the case before the proper court. In other cases, the judge decides which court is competent, and this decision binds the parties and the judge to whom the case is sent. ${ }^{50}$

\section{VI}

\section{Provisional Orders, Urgent Measures, and Ex Parte Orders}

\section{A. Ordonnances de Réferé}

Articles 484 through 492 set forth general rules relating to those urgent and/or temporary decisions (ordonnances de réferé) of immediate effect which are not in theory decisions on substantive issues. It is not unusual that a dispute ends with the decision en réferé; however, notice must be given to the opposing parties before such an order can be issued.

The chief justice of the lower court or his delegate sitting as a single judge (the

43. Id. art. 85 .

44. See infra note 91 .

45. C. PR. CrV art. 99 (66e ed. Petits Codes Dalloz 1984); Judgment of July 6, 1966, Cass. civ. 2e, 1966 J.C.P. I No. 14860; Judgment of Apr. 21, 1967, Cass. civ. 2e, 1967 J.C.P. II No. 15201 (cited in 1 R. PERROT, supra note 12, at 259).

46. C. PR. CIV. art. 78 (66e ed. Petits Codes Dalloz 1984).

47. Id. art. 79 .

48. Id. art. 94.

49. Id. art. 81

50. Id. art. 96 . 
juge des réferés) prior to litigation on the merits, may issue such temporary orders: (1) in order to find, conserve, or establish facts before litigation on the merits, sometimes through naming an expert (preventive fact finding) $;^{51}$ (2) if victims of automobile accidents or other claimants invoke this procedure, in circumstances in which there is no serious doubt as to liability, to secure a provisional judgment awarding the immediate payment of damages even before a lawsuit on the merits has been brought (réferé provision) ${ }^{52}$ (3) in order to overcome difficulties in executing judgments, but only before certain courts ${ }^{53}$ or (4) in order to grant other types of relief, such as ordering funds to be held in escrow, naming a receiver (administrateur provisioire) to manage a company, or stopping the sale of property which has been attached. ${ }^{54}$

Appeal from such an ordonnance is allowed within fifteen days. In exceptional circumstances, where an ordonnance de réferé is entered in a case on appeal by the chief justice of the court of appeals, no further appeal is allowed. ${ }^{55}$

\section{B. Ordonnances sur Requête}

Articles 493 through 498 refer to ex parte orders (ordonnances sur requête) which are issued when notice to the opposing party would not be in the interest of justice. A party aggrieved by an ordonnance sur requête must go before the judge issuing the order and secure a new ordonnance. The judges' refusal to retract the original ordinance is considered to be an ordonnance de réferé and subject to the same rules governing appeals. ${ }^{56}$

\section{Orders of the Preparatory Judges}

In cases where litigation on the merits is in progress, orders of the judge charged with preparing the case (juge de la mise en état) are also subject to an immediate appeal when they relate to temporary measures ordered in matters of divorce or separation, or to provisional sums awarded a creditor when the existence of an obligation is not subject to serious doubt. ${ }^{57}$

\section{Astreintes}

The orders referred to in this chapter may include astreintes, which are money payments ordered for failure to obey a court order. This is the French enforcement procedure resembling fines imposed in an American contempt proceeding. ${ }^{58}$

51. Id. art. 145 .

52. Id. art. 771 (3); Guide des Droits des Victimes Ministere de la Justice 251 (1984). Even if litigation on the merits has begun, such a request can be made to the preparatory judge handling the file.

Although allegations of urgency are not necessary to secure the relief sought in circumstances (1) and (2) in the text, urgency is presumed in situations where there is created a clearly illegal disorder (trouble manifestement illicite). 2 R. PERROT, supra note 12 , at 444.

53. 2 R. PERROT, supra note 12 , at 445 .

54. Id. at 441 .

55. C. PR. GIV. art. 490 (66e ed. Petits Codes Dalloz 1984).

56. 2 R. PER Rot, supra note 12 , at 614 .

57. C. PR. CIV. art. 776 (66e ed. Petits Codes Dalloz 1984).

58. Id. art. 491. 


\section{Other Judgments From Which Immediate Appeals Are SPECIFICALly AUTHORIZED}

\section{A. Disqualification of Judges and Experts}

Up until the end of the time for oral argument, a request to disqualify (récuser) a judge may be made. ${ }^{59}$ Reasons for disqualification include a personal interest in the case, relation to one of the parties, or prior counseling of one of the parties by the judge. ${ }^{60}$ If the judge refuses to disqualify himself or fails to respond to the request for disqualification, an immediate appeal can be taken to the court of appeals. ${ }^{61}$

It has also been held that an immediate appeal was available from an order refusing to replace an expert. ${ }^{62}$ The decision was not considered one of judicial administration, but an ordonnance de réferé.

\section{B. Orders to Third Parties to Produce Documents}

A third party may request withdrawal or modification of an order compelling him to produce documents. Refusal by the judge who issued the order to accede to the request of the third party is subject to immediate appeal (within fifteen days of the entry of the order). ${ }^{63}$

\section{Decisive Oaths}

Although now a rarity, a decision to administer a decisive oath ${ }^{64}$ is a procedural decision specifically made subject to immediate appeal. ${ }^{65}$ The importance assigned to this procedure is underscored by the fact that the avocat of the party needs a special written power of attorney to request $i^{66}$ and the outcome of the case is determined by it. ${ }^{67}$ False sworn testimony of the parties is subject to a criminal penalty.

\section{Orders Awarding Expenses}

A lower court judgment concerning a dispute relating to expenses (ordonnance de (axe) is subject to immediate appeal before the chief justice of the appellate court

59. Id. art. 342 .

60. Id. art. 341

61. Id. art. 349. There are, however, two exceptions: (1) where, under articles 358 and 364 , more than one judge or the entire court is questioned (suspicion legitime); and (2) under article 349 where the judge (in the labor courts for example) is not a professional judge.

62. Judgment of June 14, 1978, Cass. civ. 2e, 1978 D.S. Jur. (informations rapides) 364.

63. C. PR. CIV. art. 141 (66e ed. Petits Codes Dalloz 1984).

64. A "decisive oath" is administered to a party when the opposing party, unable to prove a disputed fact in any other way, requests him to affirm under oath that the asserted fact is untrue. If the opponent refuses or fails to take the oath and so to testify, the fact is deemed conclusively established; if he does so affirm under oath, the fact is treated as untrue. Judgment is entered accordingly, and credibility is not at issue. See R. Schlesinger, Comparative Law: Cases-Texts-Materials 401 (4th ed. 1980).

65. C. PR. CIV. art. 320 (66e ed. Petits Codes Dalloz 1984).

66. Id. art. 322

67. A party refusing to be sworn loses on his pleadings. Id. art. 319. 
within one month. ${ }^{68}$ Court orders fixing fees of experts, technical consultants to the court, or those persons designated to verify certain facts (les constatations) also are subject to appeal before the chief justice of the court of appeals, who may refer the matter to the full court. ${ }^{69}$

\section{VIII}

\section{Discretionary APPEALS}

There are two major types of discretionary appeals in the French system. The first, appeals from judgments ordering the appointment of an expert, may be subject to appeal independently from a judgment on the substantive issues. The appeal must, however, be authorized by the chief justice of the court of appeals and justified by a very serious and legitimate reason. ${ }^{70}$ Since the question of appealability is a matter of discretion for the chief justice, there is no review of his decision by the supreme court. ${ }^{71}$

The decision to stay a proceeding is also subject to appeal if authorized by the chief justice for very serious and legitimate reasons. The chief justice of the appellate court decides the appeal if accepted. ${ }^{72}$ A judgment refusing to stay a proceeding and deciding the merits of the case is subject to appeal. ${ }^{73}$

\section{IX}

\section{Situations Where French Law Specifically Denies an IMMEDIATE APPEAL}

The following are circumstances in which, under French law, there is no immediate appeal or no appeal whatsoever:

(1) Consolidation and severance. Decisions relating to consolidation of litigation, and the severance of cases pending before a chamber, are considered to be discretionary (mesures d'administration judiciaire) and not subject to appeal. ${ }^{74}$

Problems of consolidation (connexité) of different chambers of the same court are determined by the chief justice as a measure of judicial administration and are not subject to appeal. ${ }^{75}$

(2) Fact finding. Except in cases specified by law, decisions ordering or modifying orders relating to fact finding (mesures d'instruction) are not subject to opposition nor can they be appealed separately from the final judgment. ${ }^{76}$

(3) Removal from docket. A judge's decision to remove the case from the court's docket (radiation) is not an appealable order; it is, rather, the exercise of a measure of judicial administration. ${ }^{77}$ The case may be reinstated on the calendar if péremption has not occurred

68. Id. art. 714. For the rules relating to determining expenses and appeals, see id. arts. 704-18.

69. Id. art. 724,717 .

70. Id. art. 272. If the appointment of an expert, however, is decided by ordonnance de referé, appeal is always allowed. Judgment of Feb. 26, 1974, Cour d'appel, Paris, 1974 J.C.P. II No. 17748.

71. J. VinCENT \& S. GuinchaRD, supra note 3, at 822 \& n.3; Judgment of May 16, 1979, Cass. civ. 2e, 1979 Gaz. Pal. 398.

72. C. PR. CIV arts. 380, 380-1 (66e ed. Petits Codes Dalloz 1984).

73. J. VinCENT \& S. GuinchaRd, supra note 3, I 917, at 823 \& n.4; Judgment of Oct. 16, 1978, Cour d'appel, Paris, 1979 J.C.P. II No. 19098.

74. C. PR. CIV. arts. 367-68 (66e ed. Petits Codes Dalloz 1984)

75. Id. art. 107 .

76. Id. art. 150

77. Id. art. 382 
due to inaction of the parties for more than two years. ${ }^{78}$

(4) Preparatory judge's orders in appellate court. An order of a preparatory judge is not subject to immediate review separate from the final judgment, except that it may be reviewed by the full court if it terminates the litigation. ${ }^{79}$

(5) Improper service. A decision holding service of the complaint invalid is not subject to appeal. ${ }^{80}$

(6) Reorganizations and liquidations. Among the judgments relating to reorganizations and liquidations that are not subject to appeal are: (a) those relating to the appointment of juges commissaires, receivers, and supervisors (contrôleurs); (b) those involving admission of claims after time for objection has passed; (c) those of the juge commissaire, except for decisions relating to possession of property (revendications); and (d) those authorizing the continuing operation of the business, except when made in excess of one year after a decision to liquidate. In addition, where a bankruptcy court, in liquidating assets of the bankrupt, approves an agreement to sell to a third party (vente a forfait) no opposition, appeal, or review by the appellate court or the supreme court is allowed, not even by the Procureur de la République (the government's magistrate who reviews court decisions in certain cases to protect the public interest). There is, nevertheless, an exceptional right to appeal relating to a judgment authorizing the receiver to negotiate an agreement to sell assets for the Procureur. ${ }^{8 !}$

(7) Real estate attachments. Appeal of a default judgment relating to a real estate attachment is limited to defenses on the merits involving incapacity of one of the parties, rights to the property, or the allegation that the property is neither subject to attachment nor saleable. ${ }^{82}$

(8) Arbitration-amiable compositeur. Under France's arbitration rules no appeal is allowed, in the absence of a specific agreement, if the parties have specified that the arbitrator is to reach his decision as an "amiable compositeur" (using equitable principles). ${ }^{83}$

\section{$\mathrm{X}$ \\ CONCLUSION}

\section{A. French Appellate Rules}

The French system of determining when judgments or court decisions are subject to appeal is not primarily based on the "final judgment" concept. Article 543 of the Code of Civil Procedure states the general rule that unless otherwise provided, all lower court judgments (jugements de première instance) in all subject matters, including noncontentious matters, are appealable. ${ }^{84}$ Article 453 does not contain the words "final judgment," but it implicitly refers only to final judgments.

The finality requirement for appealability is evoked explicitly, but only incidentally, in article 544. The last sentence of this article provides that any decision which terminates the case is subject to appeal. ${ }^{85}$ Here the finality rule is explicit but it is inserted in this article as a catchall for appealability rather than a funda-

78. Id. arts. 383,386

79. Id. art 914 .

80. Id. art. 407. This article provides that only the judge who holds that service has lapsed may reconsider his judgment. Jurisclasseur Procédure Civile, Fascicule 712, 2E cahier Voits de Recours 3, I 12 (March 1982).

81. Law No. 67-563 of July 13, 1967, art. 103, 1967 J.O. 7059, 1967 D.S.L. 259; Judgment of June 27, 1983, Cour d'appel, Bordeaux, Gaz. Pal., Aug. 26, 1983, Recueil Bimestriel No. 4, Jurisprudence 467.

82. C. PR. CIV. art. 731 (33e ed. Codes et lois usuels, Code d'audience Dalloz 1969).

83. C. PR. CIV. art. 1482 (66e ed. Petits Codes Dalloz 1984).

84. Id. art. 543; see supra text accompanying note 17.

85. Id. art. 544; see supra text accompanying notes 19-21. 
mental principle of appealability. Thus, finality is a touchstone for appealability, but it is not the only one.

In addition to the rule that a final judgment is, unless otherwise provided, appealable, we have seen that articles 544 and 606 set out another rule framed in general terms which allows immediate limited appeal from a judgment which does not end the litigation. ${ }^{86}$ This occurs when a decision on part of the merits (une partie du principal) is made, and further fact finding is ordered or temporary relief is granted. Such a decision on the merits is a definitive judgment in the sense that it is res judicata, but it is not final in the sense of disposing of all issues as to all of the parties and terminating the litigation. Moreover, it is nonfinal in that it is not subject to normal appeal (dernier ressort). Such a decision, however, even if it does not terminate the litigation as to all issues, can be significant and an indication of what the ultimate decision will be, or it may sound the "death knell" for one of the parties. The rule allowing immediate and limited appeal from such judgments seems to be particularly fitting for long, complex litigation where opportunity for an appeal prior to a final judgment may avoid wasting time going down an erroneous path.

Part V provides examples of appeals taken on the basis of article 544 and discusses the hesitation and lack of uniformity of the decisions under the rules set forth in this provision. The drafters of the new Code opted to deny immediate appeals if a decision on the substance and on further fact finding or temporary relief is not formally in the holding section of the judgment. They believed it more important to cut off dilatory appeals than to correct a judge's error when he made a decision on a substantive issue but failed to write it into the holding. Some courts have refused to apply this formalistic rule when an important issue was in fact decided, thus warranting an immediate appeal. ${ }^{87}$

Article 545 completes the general rules relating to appealability by stating that judgments other than those on the merits (sur le fond) cannot be appealed except where specifically allowed by the law. 88

In reference to the special rules found in the new Code, the most important concern is choice-of-forum appeals (contredit) which provide for a special accelerated procedure. ${ }^{89}$ This system appears to be generally satisfactory to French practitioners although several months can pass before the appellate court renders its decision. Complications can arise if an appeal is mistakenly taken, rather than a contredit, since the latter must be brought within fifteen days while one month may elapse before an appeal is filed.

Some of the other more important rules are those permitting immediate appeals from judgments rendered by a single judge, such as injunctions, temporary relief, and in particular judgments ordering immediate payments pending final decisions.

The French rules also allow discretionary appeals from judgments concerning

86. See supra text accompanying notes 18-19, 29.

87. See supra text accompanying notes $27-30$.

88. C. PR. CIV. art. 545 (66e ed. Petits Codes Dalloz); see supra text accompanying notes 22-24.

89. See supra text accompanying notes 40-44. 
stays and the appointment of experts. Although neither type of judgment decides the merits or ends the litigation, both can involve serious matters for litigants, justifying an immediate appeal where circumstances warrant. This general kind of a solution is allowed in a different context in American practice when a party seeks clarification of controlling questions of law under section 1292(b) of the Judicial Code. ${ }^{90}$

\section{B. Comparison of Systems}

After this quick trip across the French legal scheme, it can be concluded that the French system is reasonably well organized. It starts with general rules, sets forth specific rules for specific situations, reserves two situations for discretionary appeals, and specifically negates immediate (or any) appeal in some cases.

The finality rule in French law is not as important a rule as in U.S. law. In addition, if one considers the basic principle of French procedural law that each litigant is entitled on appeal to another chance to prevail on the law and the facts, one might conclude that with regard not only to the allowance of immediate appeals but also to the scope of appeals generally, the French system, where an appeal is in fact more like a new trial, is the more liberal of the two countries' practices.

On the other hand, the U.S. system allows, in extraordinary circumstances, the issuance of discretionary writs which are unknown in the French system and which provide greater possibility for appeals. Similar types of review, however, are available in France within the normal system of review. Supreme court review to correct an excès de pouvoir (exercise of excessive power by a lower court) is an example. The emphasis on the finality rule in U.S. procedure may be in part due to the influence of the jury system and the resulting concentration of trials into a single event in a continuous time span necessitated by the presence of the jury. In France the procedure is discontinuous; this is possible because the procedure is primarily written, except for the oral argument after documents have been exchanged and the completion of fact finding ordered by the court. ${ }^{91}$ Therefore the interruption caused by an appeal is less disruptive of proceedings under the French system than it would be during the course of a jury trial under the U.S. system.

Case law in the United States has carved out exceptions to the finality rule. This indicates that the rule is too stringent in many circumstances. Perhaps rules should be adopted with more explicit exceptions, some of which could be discretionary, and recourse provided to accelerated procedures for certain interlocutory appeals. Litigants could be subject to sanctions for dilatory appeals as in the French system. ${ }^{92}$ However, whether consideration of any of the French rules could

90. 28 U.S.C. $§ 1292$ (b) (1982).

91. For a discussion of concentrated and discontinuous trials, see Von Mehren, The Significance for Procedural Practice and Theory of Concenirated Trial: Comparative Remarks, in EUROPAISCHES RECHTSDENkEN IN Geschichte UND GeGenwart (Munchen 1982).

92. Articles 88 and 559 provide for fines and damages in case of dilatory or abusive contredits or appeals. C. PR. CIV. arts. 81, 559 (66e ed. Petits Codes Dalloz 1984). If there were unlimited recourse to piecemeal appeals there would be so many appeals that they would not be accelerated. 
serve as inspiration for law reform in the United States requires further study since there are significant differences in the legal systems. 